\title{
Pattern and levels of spending allocated to HIV prevention programs in low- and middle-income countries
}

\author{
Peter Amico ${ }^{1}$, Benjamin Gobet ${ }^{2}$, Carlos Avila-Figueroa ${ }^{3 *}$, Christian Aran $^{2}$ and Paul De Lay ${ }^{2}$
}

\begin{abstract}
Background: AIDS continues to spread at an estimated 2.6 new million infections per year, making the prevention of HIV transmission a critical public health issue. The dramatic growth in global resources for AIDS has produced a steady scale-up in treatment and care that has not been equally matched by preventive services. This paper is a detailed analysis of how countries are choosing to spend these more limited prevention funds.

Methods: We analyzed prevention spending in 69 low- and middle-income countries with a variety of epidemic types, using data from national domestic spending reports. Spending information was from public and international sources and was analyzed based on the National AIDS Spending Assessment (NASA) methods and classifications.

Results: Overall, prevention received $21 \%$ of HIV resources compared to $53 \%$ of funding allocated to treatment and care. Prevention relies primarily on international donors, who accounted for $65 \%$ of all prevention resources and $93 \%$ of funding in low-income countries. For the subset of 53 countries that provided detailed spending information, we found that $60 \%$ of prevention resources were spent in five areas: communication for social and behavioral change (16\%), voluntary counselling and testing (14\%), prevention of mother-to-child transmission (13\%), blood safety (10\%) and condom programs (7\%). Only $7 \%$ of funding was spent on most-at-risk populations and less than $1 \%$ on male circumcision. Spending patterns did not consistently reflect current evidence and the HIV specific transmission context of each country.
\end{abstract}

Conclusions: Despite recognition of its importance, countries are not allocating resources in ways that are likely to achieve the greatest impact on prevention across all epidemic types. Within prevention spending itself, a greater share of resources need to be matched with interventions that approximate the specific needs and drivers of each country's epidemic.

\section{Background}

In the third decade of the HIV epidemic, people are starting to adopt safer sexual behaviors, reflecting the impact of HIV prevention and awareness efforts [1]. There is evidence linking prevention strategies to reduction of incidence through behavioral change programs [2]. Also, there are reports of prevention program effectiveness and published estimates of the effectiveness of HIV prevention interventions in changing sexual behaviors $[3,4]$. However, some studies have shown that

\footnotetext{
* Correspondence: Carlos_Avila@abtassoc.com

${ }^{3}$ Abt Associates, 4550 Montgomery Ave, Suite 800 North, Bethesda, MD 20814, USA

Full list of author information is available at the end of the article
}

countries often do not allocate resources in ways that are likely to achieve the greatest impact; countries with similar epidemic types and prevalence rates distribute resources in radically different ways [5-7].

The United Nations Political Declaration on AIDS called to expand prevention coverage by diversifying approaches and intensify efforts to end new HIV infections and reaffirm that prevention of HIV must be the cornerstone of national, regional and international responses to the HIV epidemic [8]. Governments also committed to re-double HIV prevention efforts by taking all measures to implement comprehensive, evidencebased prevention approaches, taking into account local circumstances, ethics and cultural values [8]. Even with

\section{Biomed Central}


gains in access to treatment, the number of people newly infected continues to outpace those that are put on treatment $[9,10]$. Prevention remains the paramount challenge of the HIV epidemic and the modes of prevention are evolving with the results of the HPT 052 study [11,12]. Even with gains in access to treatment and a global decline in the number of new infections, there were an estimated 2.6 million people newly infected with HIV in 2010 [1].

As the AIDS epidemic continues to evolve, revealing geographic variations between and within regions, countries are increasingly working to formulate responses specific to their particular contexts [13]. With the continuing scale-up of the national and international AIDS response, it is increasingly important to accurately track the origin of funds and how they are spent at the national level. This includes looking at whether countries are obtaining the maximum benefit and achieving expected outcomes from their AIDS resources [14]. The mapping of resource flows can help decision-makers monitor the effectiveness of their national programs and improve resource mobilization in underfunded areas. At the global level, this allows the international community to evaluate the status of its response and its financial accountability.

\section{Methods}

An analysis of reported HIV prevention expenditures from 69 low- and middle- income countries in 2008 was conducted, taking into account epidemic types, prevention spending categories and country income levels. A subset of 53 countries contained detailed information by spending category. All expenditures, by programmatic activity and HIV services, were cross-tabulated by source of financing and stratified by income level. Spending information from public and international sources was analyzed based on the National AIDS Spending Assessment (NASA) methods and classifications [15]. Total prevention spending was collected using United Nations General Assembly Special Session on HIV/AIDS (UNGASS) Indicator No. 1 reports [14]. This indicator reports on domestic and international spending on AIDS by country, broken down into spending subcategories.

NASA is a tool developed by UNAIDS to measure all the resources included in a country's national HIV response and is based on the national health accounts framework $[16,17]$. In addition to reporting on UNGASS progress, the NASA methodology has been used to support countries in planning and monitoring their HIV activities. NASA applies standard accounting methods to reconstruct all transactions in a given country, 'following the money' from the funding sources to agents and providers, and eventually to beneficiary populations.
These data are collected from every institution and organization that intervenes financially in the national response to HIV. And they are collected by the country's NASA taskforce and entered into a Resource Tracking System (RTS).

Countries were classified by national income level. Economies were divided according to their Gross National Income (GNI) per capita for the data collection year used, calculated using the World Bank Atlas Methods and grouped into four categories: low-income (US\$ 935 or less); lower middle-income (US\$ 936 - \$3,705); upper middle-income (US\$ 3,706 - \$11,455); and high income (US\$ 11,456 or more) [18]. All prices were converted into constant 2008 dollars.

Finally, countries were grouped by type of HIV epidemic using UNAIDS and WHO classification criteria [19]. This classification identifies three epidemic typeslow level, concentrated and generalized-based on the current state of the epidemic and prevalence levels in each country. Low-level epidemics are defined as having prevalence below $1 \%$ in the general population. Concentrated epidemics are not yet generalized, but have expanded to greater than five percent among any subpopulation group and are largely confined to most-atrisk populations-commercial sex workers (CSW), men who have sex with men (MSM) and injecting drug users (IDU).

South Africa is notably absent, due to the fact that they did not report their HIV spending in 2008.

\section{Results}

The 69 low- and middle-income countries with available data spent a total of US\$ 5.1 billion on the AIDS response in 2008. Out of the 69 countries, there are 32 low-income countries, 26 lower middle-income countries and 11 upper middle-income countries. Prevention amounted to US\$ $1.1(+/-22$ million) billion of this total (21\%); however, the majority of spending was focused on treatment and care (53\%). Table 1(Reported total and per capita prevention spending, proportion of international funding and overall HIV funding allocated to prevention by epidemic type for 69 countries, in order of per capita spending, 2008 (USD)) shows the absolute and per capita amounts spent on prevention by epidemic type, the level of financing coming from international sources, the proportion of overall HIV resources that were allocated to prevention and countries' ranking with respect to per capita spending.

The study includes 15 countries with low-level epidemics, 28 with concentrated epidemics and 26 with generalized epidemics. Once adjusted by the size of their populations, countries with generalized epidemics showed higher average per capita spending on prevention-US\$ 1.82 (Range .28-15.37) compared to US\$ 0.68 
Table 1 Reported total and per capita prevention spending, proportion of international funding and overall HIV funding allocated to prevention by epidemic type for 69 countries, in order of per capita spending, 2008 (USD)

\begin{tabular}{|c|c|c|c|c|c|}
\hline Country & $\begin{array}{l}\% \text { HIV spending } \\
\text { allocated to } \\
\text { prevention }\end{array}$ & $\begin{array}{l}\text { Total prevention } \\
\text { spending (USD } \\
\text { thousands) }\end{array}$ & $\begin{array}{l}\% \text { of total prevention spending } \\
\text { funded by international donors }\end{array}$ & $\begin{array}{l}\text { Per capita } \\
\text { prevention } \\
\text { spending }\end{array}$ & $\begin{array}{l}\text { Ranking by per capita } \\
\text { prevention spending }\end{array}$ \\
\hline
\end{tabular}

Low-level epidemics

\begin{tabular}{|c|c|c|c|c|c|}
\hline Kyrgyzstan & 63 & 5,547 & 88 & 1.01 & 17 \\
\hline Georgia & 40 & 3,218 & 77 & 0.75 & 24 \\
\hline Cuba & 12 & 5,543 & 25 & 0.48 & 35 \\
\hline Tajikistan & 47 & 2,930 & 77 & 0.42 & 42 \\
\hline Azerbaijan & 70 & 3,512 & 27 & 0.39 & 45 \\
\hline $\begin{array}{l}\text { Iran (Islamic } \\
\text { Republic of) }\end{array}$ & 57 & 20,402 & 9 & 0.27 & 51 \\
\hline $\begin{array}{l}\text { Lao People's } \\
\text { Democratic } \\
\text { Republic } \\
\end{array}$ & 31 & 1,571 & 100 & 0.25 & 55 \\
\hline Bolivia & 40 & 2,178 & 60 & 0.22 & 56 \\
\hline Bangladesh & 69 & 25,566 & 100 & 0.16 & 61 \\
\hline Morocco & 37 & 4,685 & 71 & 0.14 & 62 \\
\hline Pakistan & 68 & 9,709 & 24 & 0.06 & 65 \\
\hline Sri Lanka & 66 & 1,030 & 100 & 0.05 & 66 \\
\hline Philippines & 53 & 3,462 & 74 & 0.04 & 67 \\
\hline Egypt & 35 & 2,601 & 50 & 0.03 & 68 \\
\hline Algeria & 11 & 432 & 41 & 0.01 & 69 \\
\hline \multicolumn{6}{|c|}{ Concentrated epidemics } \\
\hline $\begin{array}{l}\text { Republic of } \\
\text { Moldova }\end{array}$ & 70 & 8,966 & 59 & 2.28 & 6 \\
\hline Honduras & 59 & 14,420 & 56 & 1.86 & 9 \\
\hline Costa Rica & 33 & 6,480 & 9 & 1.39 & 11 \\
\hline El Salvador & 21 & 8,338 & 25 & 1.35 & 12 \\
\hline Cambodia & 38 & 19,929 & 79 & 1.31 & 13 \\
\hline Belarus & 66 & 12,365 & 14 & 1.25 & 14 \\
\hline Chile & 23 & 20,321 & 2 & 1.19 & 15 \\
\hline Mali & 30 & 11,987 & 91 & 0.98 & 18 \\
\hline Argentina & 14 & 35,216 & 12 & 0.88 & 22 \\
\hline Thailand & 22 & 45,287 & 21 & 0.71 & 25 \\
\hline $\begin{array}{l}\text { Dominican } \\
\text { Republic }\end{array}$ & 23 & 5,450 & 73 & 0.52 & 33 \\
\hline Ukraine & 23 & 22,808 & 63 & 0.48 & 36 \\
\hline Peru & 34 & 14,135 & 73 & 0.47 & 37 \\
\hline Mexico & 19 & 50,606 & 1 & 0.45 & 39 \\
\hline Colombia & 20 & 20,788 & 0 & 0.45 & 40 \\
\hline Viet Nam & 36 & 39,344 & 89 & 0.44 & 41 \\
\hline Malaysia & 45 & 11,000 & 0 & 0.39 & 44 \\
\hline Armenia & 42 & 1,100 & 77 & 0.36 & 47 \\
\hline Gambia & 11 & 563 & 100 & 0.34 & 49 \\
\hline Myanmar & 47 & 15,546 & 94 & 0.27 & 52 \\
\hline Panama & 7 & 922 & 77 & 0.26 & 53 \\
\hline Madagascar & 42 & 5,003 & 75 & 0.26 & 54 \\
\hline Brazil & 7 & 41,759 & 3 & 0.21 & 57 \\
\hline Venezuela & 8 & 5,662 & 1 & 0.20 & 58 \\
\hline
\end{tabular}


Table 1 Reported total and per capita prevention spending, proportion of international funding and overall HIV funding allocated to prevention by epidemic type for 69 countries, in order of per capita spending, 2008 (USD) (Continued)

\begin{tabular}{|c|c|c|c|c|c|}
\hline Niger & 23 & 2,822 & 96 & 0.20 & 59 \\
\hline Paraguay & 13 & 1,164 & 51 & 0.18 & 60 \\
\hline Somalia & 18 & 1,088 & 100 & 0.12 & 63 \\
\hline Indonesia & 50 & 24,703 & 61 & 0.10 & 64 \\
\hline \multicolumn{6}{|c|}{ Generalized epidemics } \\
\hline Botswana & 9 & 29,766 & 66 & 15.37 & 1 \\
\hline Lesotho & 12 & 9,869 & 67 & 4.84 & 2 \\
\hline Kenya & 24 & 158,619 & 97 & 4.14 & 3 \\
\hline Rwanda & 26 & 29,308 & 98 & 3.16 & 4 \\
\hline Gabon & 38 & 4,542 & 8 & 3.11 & 5 \\
\hline Uganda & 22 & 64,185 & 100 & 1.97 & 7 \\
\hline Mozambique & 27 & 38,543 & 97 & 1.86 & 8 \\
\hline Malawi & 19 & 20,598 & 98 & 1.42 & 10 \\
\hline Congo & 35 & 4,118 & 100 & 1.12 & 16 \\
\hline Cote d'Ivoire & 31 & 19,417 & 99 & 0.94 & 19 \\
\hline Togo & 38 & 5,887 & 97 & 0.89 & 20 \\
\hline Burkina Faso & 27 & 12,956 & 71 & 0.88 & 21 \\
\hline Guinea-Bissau & 34 & 1,238 & 96 & 0.78 & 23 \\
\hline Eritrea & 25 & 3,574 & 93 & 0.71 & 26 \\
\hline $\begin{array}{l}\text { Central African } \\
\text { Republic }\end{array}$ & 15 & 3,031 & 92 & 0.70 & 27 \\
\hline Angola & 38 & 12,215 & 16 & 0.68 & 28 \\
\hline Benin & 28 & 5,745 & 81 & 0.65 & 29 \\
\hline Senegal & 28 & 7,148 & 87 & 0.60 & 30 \\
\hline Cameroon & 29 & 11,435 & 82 & 0.59 & 31 \\
\hline Burundi & 22 & 5,736 & 81 & 0.54 & 32 \\
\hline Chad & 38 & 5,323 & 100 & 0.49 & 34 \\
\hline Equatorial Guinea & 12 & 329 & 100 & 0.47 & 38 \\
\hline Guinea & 31 & 4,087 & 100 & 0.40 & 43 \\
\hline Nigeria & 15 & 57,949 & 89 & 0.38 & 46 \\
\hline Ghana & 22 & 8,307 & 83 & 0.35 & 48 \\
\hline $\begin{array}{l}\text { Democratic } \\
\text { Republic of the } \\
\text { Congo }\end{array}$ & 21 & 18,115 & 97 & 0.28 & 50 \\
\hline
\end{tabular}

(Range .10-2.28) in concentrated epidemics and US\$ 0.29 (Range .01-1.01) in low-level epidemics. The greatest share of HIV resources going to prevention was in low-level epidemics, where $45 \%$ of funds went to prevention, compared to $20 \%$ in concentrated epidemics and $21 \%$ for generalized epidemics. Figures 1, 2 and 3 provide a breakdown of HIV spending by epidemic type and income level for all countries. Prevention spending patterns vary greatly, even among similar epidemic profiles and income levels.

Currently, prevention relies heavily on international donors. On average 38\% of total financing for prevention came from domestic-public sources, in contrast to the $63 \%$ of total treatment expenditures that were funded domestically. International funding for prevention was highest in low-income countries, where it reached a median value of $95 \%$ (Range 24-100\%), compared to $59 \%$ (Range 0-100\%) in lower-middle income countries and $8 \%$ (Range $0-100 \%$ ) in upper-middle income ones. In 46 countries, international sources were responsible for over $60 \%$ of prevention resources, with contributions of greater than $80 \%$ in 31 of those countries. The majority of these are low-income countries, although this group also included Equatorial Guinea.

Many of the countries benefitting from international assistance were from sub-Saharan Africa, which 


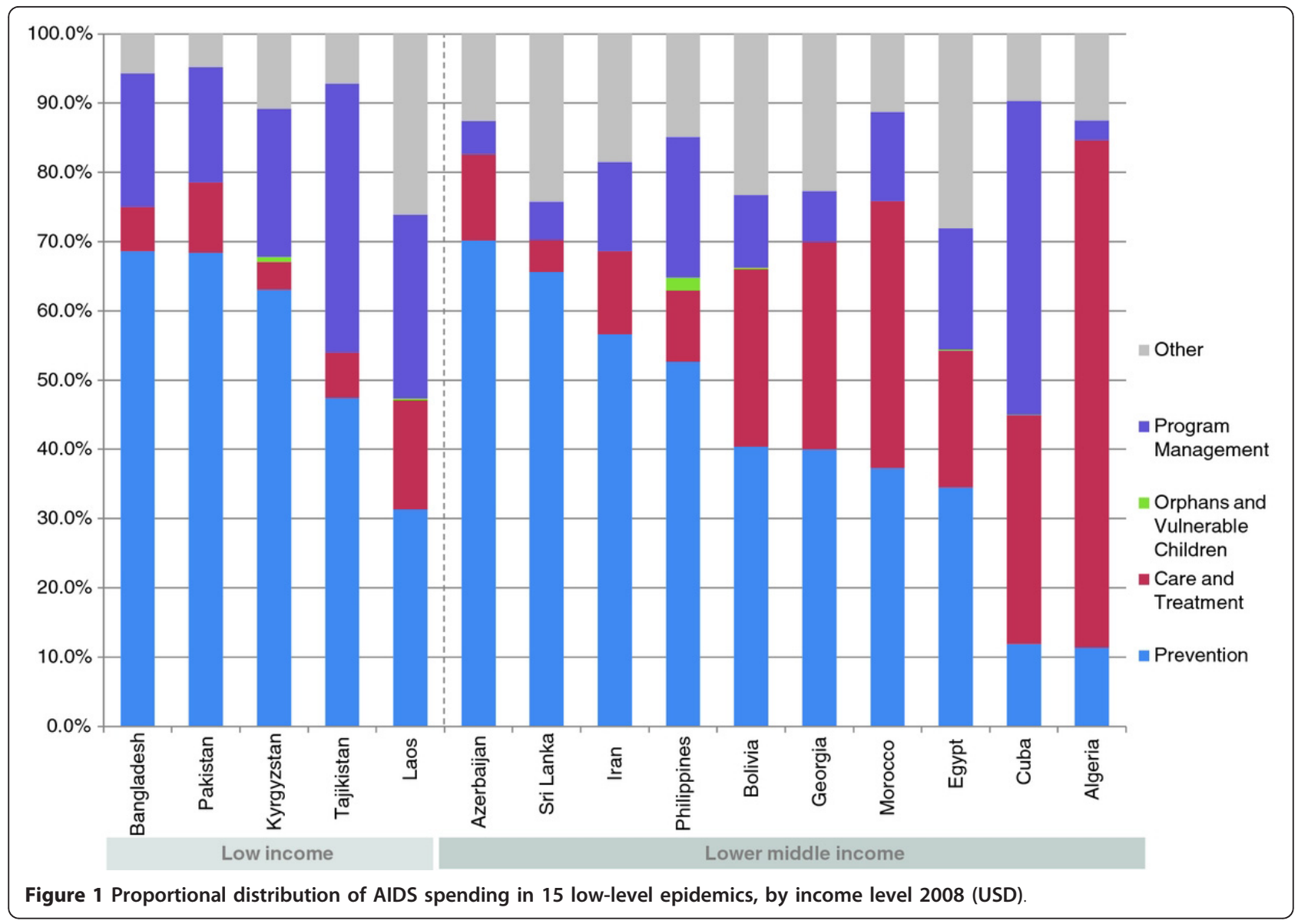

registered both the highest levels of per capita spending on prevention and the greatest proportion of resources coming from international donors. SubSaharan Africa received $90 \%$ of its prevention resources from international donors, compared to $62 \%$ in South and South East Asia, 54\% in Eastern Europe and Central Asia, 27\% in the Middle East and North Africa, and 15\% in Latin America and the Caribbean. Per capita, sub-Saharan African countries spent US\$ 1.01 on prevention, the highest among any other region. Eastern Europe and Central Asia was the second highest spender at US\$ 0.67 per capita, followed by Latin America and the Caribbean at US\$ 0.43, South and South East Asia at US\$ 0.21 and the Middle East and North Africa at US\$ 0.12.

In absolute terms, Kenya (US\$158. 6 million), Uganda (US\$ 64.2 million), Nigeria (US\$ 57.9 million), Mexico (US\$ 50.6 million) and Thailand (US\$ 45.3 million) are the biggest prevention spenders. Botswana (US\$ 15.37), which has invested heavily in its AIDS programs in recent years, has the highest per capita spending, followed by Lesotho (US\$ 4.84), Kenya (US\$ 4.14), Rwanda (US\$ 3.16) and Gabon (US\$ 3.11). Figure 4 is a representation of the 25 countries that spent the most on prevention and it shows both domestic and public sources of finance. Among the top 25 spenders, 12 relied on international sources for over $75 \%$ of their expenditures.

Table 2 (Total and proportional spending per prevention category in 53 countries, by epidemic type, 2008 (USD thousands)) presents expenditure by type of epidemic in relation to 23 prevention categories for the subset of 53 countries that provided detailed reports. Communication for social and behavioral change (16\%), voluntary counselling and testing (14\%) and prevention of mother-to-child transmission (13\%) received the largest share of funds. These were followed by blood safety $(10 \%)$ and prevention and treatment of STIs (6\%). Notably, male circumcision and post-exposure prophylaxis both received less than $1 \%$ of overall prevention funding. Condom-related categories including, social marketing, public and commercial sector male/female condom provision, accounted for $7 \%$ of funding.

Programs for the most-at-risk-populations (MARPS) each received $3 \%$ or less of overall funding, although proportional spending was higher in low-level epidemics. 


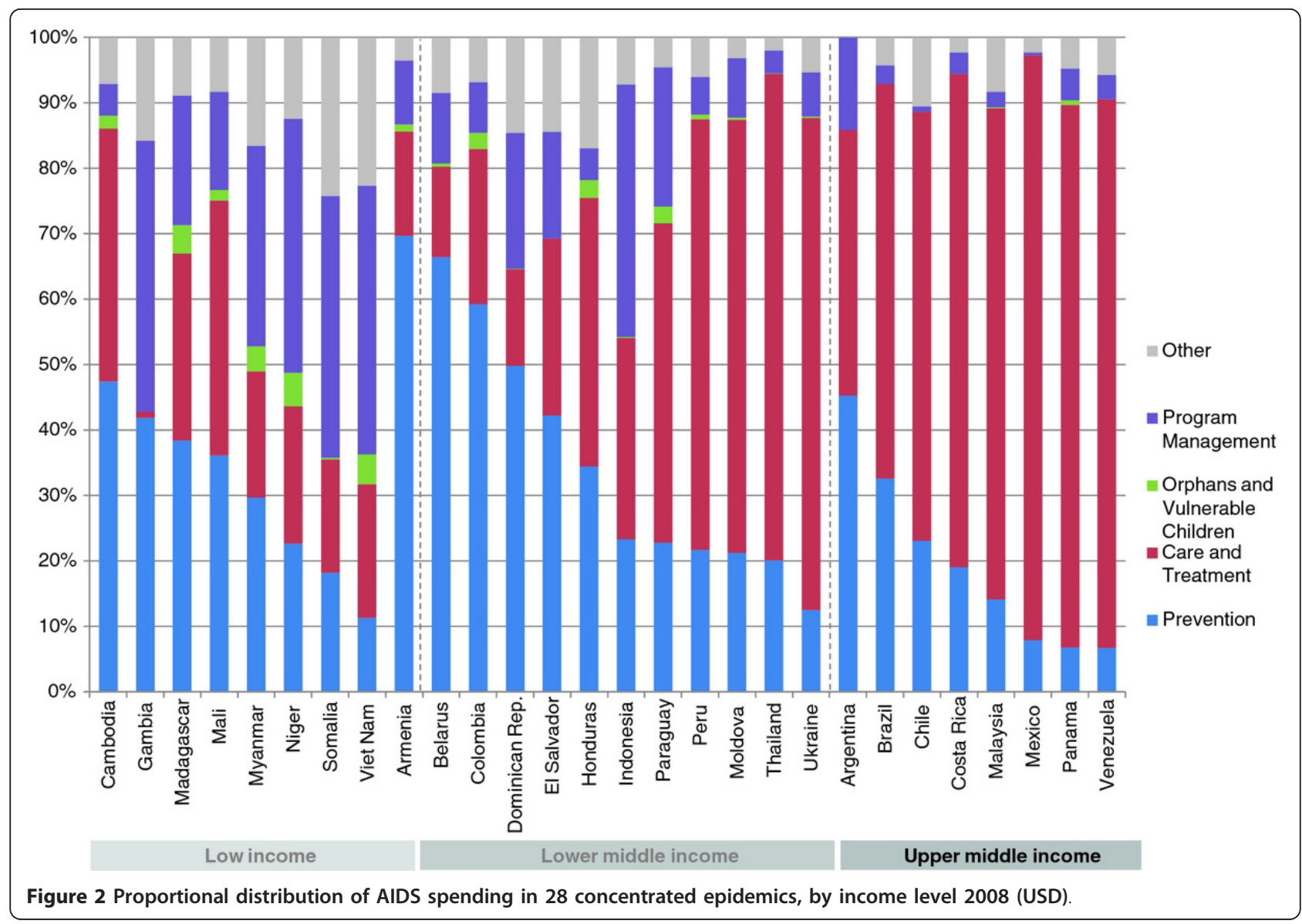

Overall, low-level epidemics spent $25 \%$ of their prevention budget on higher risk groups, compared to $12 \%$ in concentrated epidemics and just over $1 \%$ in generalized epidemics. This was due mainly to higher investments in harm reduction programs, which received $15 \%$ of prevention funds in low-level epidemics, compared to $5 \%$ of total resources in concentrated epidemics and less than $1 \%$ in generalized epidemics. Programs for MSM were allocated $4 \%$ or less of resources in each epidemic type, while initiatives targeting CSWs received $6 \%$ or less.

\section{Discussion}

The countries in this study spent just over a fifth of all resources for their AIDS response on prevention, providing a detailed picture of programmatic allocations of just over US\$ 1 billion. While this analysis focused on prevention, these investments took place within the larger context of concurrent expenditures on treatment and care, orphans and vulnerable children, and program support and research, which brought total AIDS spending in 2008 to US\$ 5.1 billion in the countries studied. Many of the prevention categories have low proportions of spending, but this does not necessarily mean that the spending is insufficient. This depends on the size of the target population and the amount that is spent. The recent Investment Framework proposes focused programs for high risk populations, elimination of HIV infections in children, reduction of risk through behaviour change, enhanced condom programs, treatment for people living with HIV and voluntary male circumcision in countries with high prevalence and low circumcision rates [20].

International funding is particularly prominent in prevention activities focused on MARPS, where it is the main source of overall funding, but it is likely that broader issues related to stigma, political will and human rights remain significant factors influencing domestic resource allocations. At least 42 countries in the study have laws criminalizing activities related to one or more MARPS [21]. Decreased donor contributions will result in reduced funding for these groups and domestic resources do not often make up the gap. Sustaining long-term preventive services in these populations could present a serious challenge, particularly in low-income countries.

Of the 26 countries with generalized epidemics in the study, 25 are located in sub-Saharan Africa, a region which accounts for an estimated two-thirds of the global 


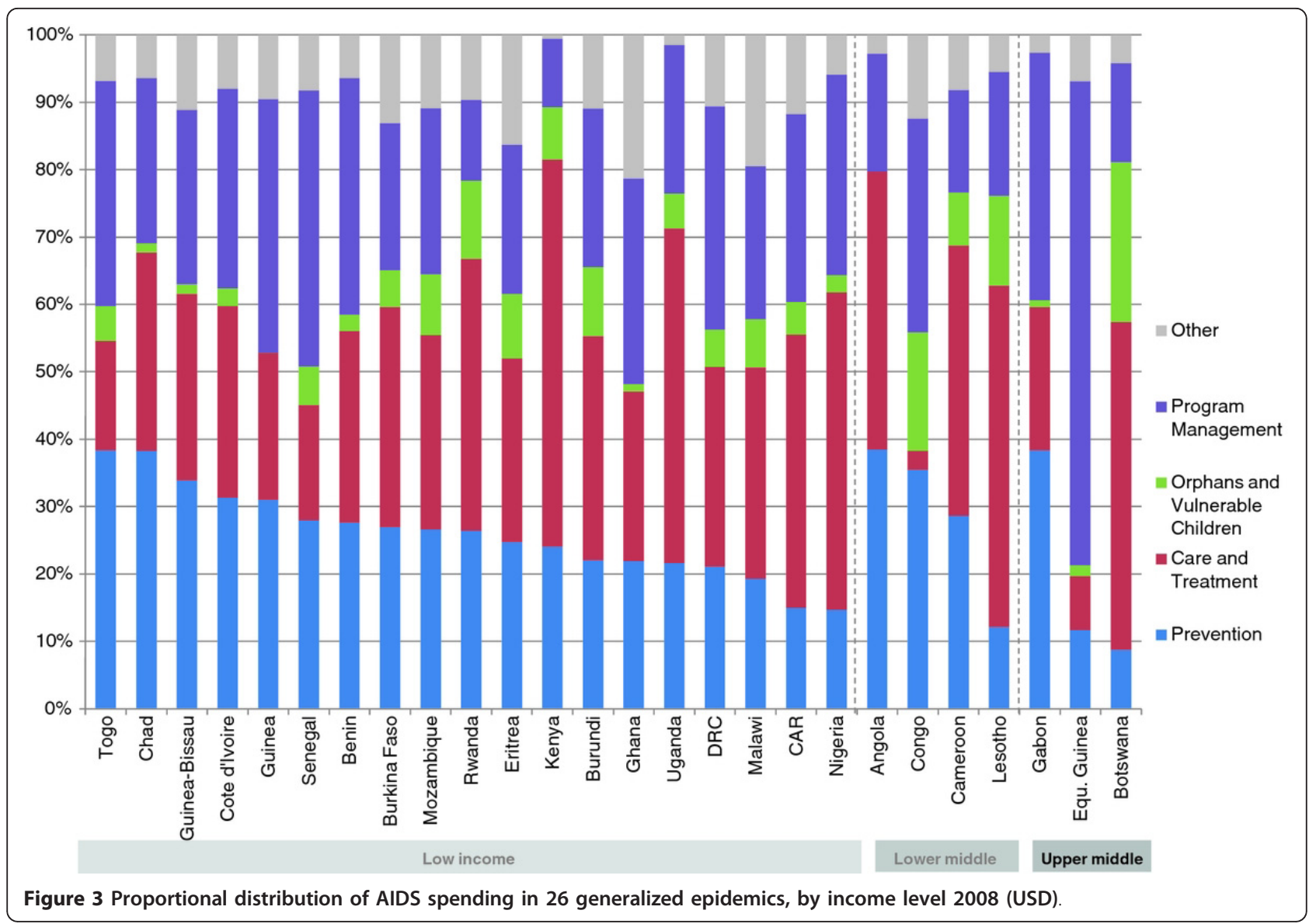

HIV epidemic [22]. In these countries, it is essential to address sexual prevention, which have been reported as a key factor in the region's high levels of HIV transmission [9]. This requires simultaneous implementation of a variety of risk-reduction strategies. A key approach typically relies on messaging targeting a particular subpopulation. In the 22 countries with generalized epidemics that provided a detailed breakdown of their spending, mass media campaigns, community mobilization and workplace prevention programs together accounted for $27 \%$ of prevention spending. VCT received $17 \%$, while $20 \%$ was invested in PMTCT and $5 \%$ was put towards ensuring a safe blood supply. Communication for behavioral change was the top prevention spending category in generalized epidemics. Uganda has experienced success through its 1987 "Zero Grazing" campaign and appears to have reduced the percentage of men having multiple partnerships [23].

Currently, there is wide interest in using antiretroviral therapy as a means to prevent HIV transmission [24,25]. Evidence from PMTCT programs and follow-up studies of discordant couples has demonstrated a significant reduction in HIV transmission through ART [26]. Preliminary results from the HPTN 052 study show that
ART is $96 \%$ effective in preventing transmission to an uninfected sexual partner in discordant couples where the index case has CD4 counts between 350 and 550 [11]. It is therefore plausible that early antiretroviral therapy and wide coverage could reduce community viral loads and significantly reduce the number of new cases of HIV [27,28]. HIV testing can act as an entry point to both effective prevention and treatment, and bridge the gap between these two approaches.

Increasing consistent use of condoms requires strategies that go beyond supplying condoms to increase demand and motivation for their use. Roughly, four percent of spending in generalized epidemics was allocated to the provision of condoms, while $3 \%$ of resources were used for condom social marketing activities. A few countries in the region did direct a large proportion of their prevention resources to condom-programs.

In generalized epidemics in sub-Saharan Africa male circumcision accounts for a small proportion of overall spending, with only four countries reporting expenditures in this area. Male circumcision has been shown to be highly cost effective $[29,30]$. A randomized control trial found that male circumcision has the potential to reduce the risk of HIV in men by $60 \%$ [29]. The lack of 


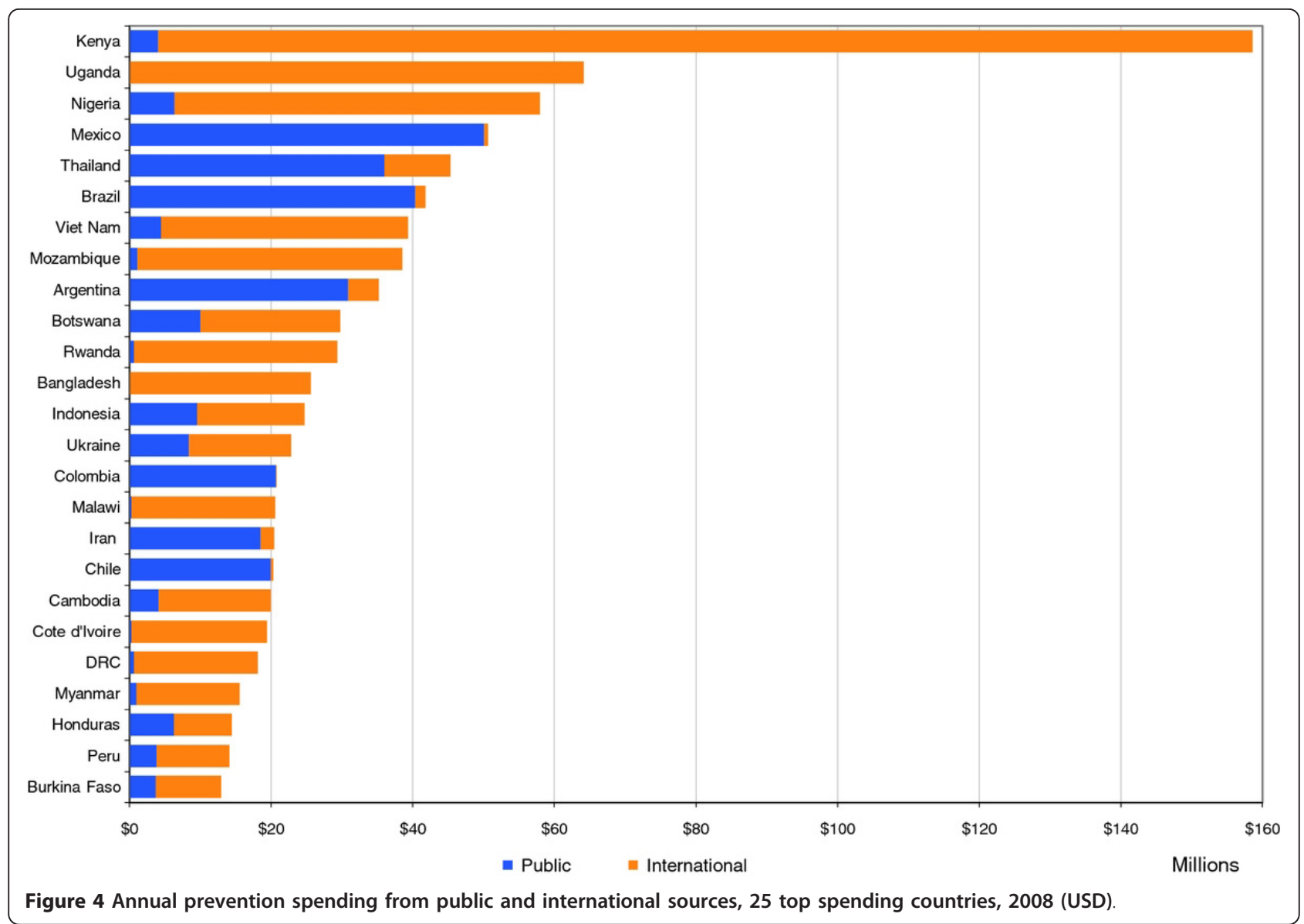

spending in this area may be understandable, given that wide advocacy for this option really began in 2008. In June 2009, Population Services International received a five-year, US $\$ 50$ million grant from the Bill and Melinda Gates Foundation to provide voluntary male circumcision services to 650,000 men in Swaziland and Zambia, while Zimbabwe has expanded a pilot program and is now aiming to circumcise $80 \%$ of its male population by the end of 2025 [30,31]. There will likely be priority shifts and new trends in the future.

This study has several limitations; there is a lack of data to compare observed HIV spending levels with spending targets or populations at risk in the country. The data that do exist are highly unreliable and the authors determined that it was more instructive to present a global perspective of prevention than to compare spending to target population size. Also, expenditures are estimated using different sources of information and some countries lack comprehensive and regular expenditure records and accounting information systems. This analysis does not include out-of-pocket expenditures; although out-of-pocket spending has been found to vary from 23 to $68 \%$ of total health expenditures, the proportion that households divert to the purchase of condoms, HIV testing, clean syringes or other preventive interventions is unknown [32].

\section{Conclusions}

Substantial changes are needed to achieve a more targeted and strategic approach to investment in the response to the HIV/AIDS epidemic that will yield longterm dividends. Until now, advocacy for resources has been done on the basis of a commodity approach that encouraged scaling up of numerous strategies in parallel, irrespective of their relative effects [20]. The United Nations Political Declaration on AIDS commits to ensure that financial resources for prevention are targeted to evidence-based prevention measures that reflect the specific nature of each country's epidemic by focusing on geographic locations, social networks and populations vulnerable to HIV infection [8]. It is important that prevention and treatment be viewed not as competing interests, but as complementary activities that together provide the basis for combined prevention approaches that address each country's context. This overview of prevention spending may be a catalyst for 
Table 2 Total and proportional spending per prevention category in 53 countries, by epidemic type, 2008 (USD thousands)

\begin{tabular}{|c|c|c|c|c|c|c|c|c|}
\hline & & & $\begin{array}{l}\text { Low- } \\
\text { level }\end{array}$ & & Concentrated & & Generalize & \\
\hline AIDS spending category & Total & $\begin{array}{c}\% \\
\text { spending }\end{array}$ & Total & $\begin{array}{c}\% \\
\text { spending }\end{array}$ & Total & $\begin{array}{c}\% \\
\text { spending }\end{array}$ & Total & $\begin{array}{c}\% \\
\text { spending }\end{array}$ \\
\hline Communication for social and behavioral change & 107,373 & $16 \%$ & 5,058 & 12 & 35,040 & 11 & 67,275 & 21 \\
\hline Voluntary counselling and testing (VCT) & 91,408 & $14 \%$ & 1,665 & 4 & 32,589 & 11 & 57,154 & 18 \\
\hline Prevention of mother-to-child transmission & 87,913 & $13 \%$ & 854 & 2 & 34,980 & 11 & 52,079 & 16 \\
\hline Blood safety & 69,542 & $10 \%$ & 5,252 & 13 & 41,271 & 13 & 23,019 & 7 \\
\hline $\begin{array}{l}\text { Prevention, diagnosis and treatment of sexually } \\
\text { transmitted infections (STI) }\end{array}$ & 40,937 & $6 \%$ & 1,507 & 4 & 36,081 & 12 & 3,348 & 1 \\
\hline $\begin{array}{l}\text { Prevention activities not disaggregated by } \\
\text { intervention }\end{array}$ & 37,617 & $6 \%$ & 287 & 1 & 5,576 & 2 & 31,755 & 10 \\
\hline Community mobilization & 33,128 & $5 \%$ & 1,194 & 3 & 19,259 & 6 & 12,675 & 4 \\
\hline Condom social marketing & 30,441 & $5 \%$ & 4,340 & 11 & 6,834 & 2 & 19,267 & 6 \\
\hline $\begin{array}{l}\text { Risk-reduction for vulnerable and accessible } \\
\text { populations }\end{array}$ & 25,777 & $4 \%$ & 2,725 & 7 & 18,650 & 6 & 4,402 & 1 \\
\hline Harm-reduction programmes for injecting drug users & 22,244 & $3 \%$ & 6,275 & 15 & 15,451 & 5 & 518 & 0 \\
\hline Prevention - Youth in school & 21,414 & $3 \%$ & 1,902 & 5 & 7,034 & 2 & 12,477 & 4 \\
\hline $\begin{array}{l}\text { Prevention programmes for sex workers and their } \\
\text { clients }\end{array}$ & 19,764 & $3 \%$ & 2,555 & 6 & 13,513 & 4 & 3,696 & 1 \\
\hline $\begin{array}{l}\text { Public and commercial sector male condom } \\
\text { provision }\end{array}$ & 15,817 & $2 \%$ & 554 & 1 & 4,153 & 1 & 11,110 & 3 \\
\hline Prevention programmes in the workplace & 13,296 & $2 \%$ & 474 & 1 & 3,657 & 1 & 9,165 & 3 \\
\hline Prevention activities not elsewhere classified & 10,881 & $2 \%$ & 1,439 & 4 & 8,102 & 3 & 1,340 & 0 \\
\hline Programmes for men who have sex with men & 9,887 & $1 \%$ & 1,691 & 4 & 7,989 & 3 & 207 & 0 \\
\hline Prevention - Youth out-of-school & 9,426 & $1 \%$ & 671 & 2 & 6,779 & 2 & 1,976 & 1 \\
\hline Safe medical injections & 6,727 & $1 \%$ & 1,425 & 3 & 16 & 0 & 5,287 & 2 \\
\hline $\begin{array}{l}\text { Prevention of HIV transmission aimed at people } \\
\text { living with HIV }\end{array}$ & 5,254 & $1 \%$ & 363 & 1 & 3,160 & 1 & 1,732 & 1 \\
\hline Universal precautions & 4,802 & $1 \%$ & 537 & 1 & 4,185 & 1 & 80 & 0 \\
\hline Post-exposure prophylaxis & 2,647 & 0.00 & 1 & 0 & 2,451 & 1 & 194 & 0 \\
\hline Male circumcision & 1,089 & 0.00 & 0 & 0 & 922 & 0 & 168 & 0 \\
\hline $\begin{array}{l}\text { Public and commercial sector female condom } \\
\text { provision }\end{array}$ & 1,060 & 0.00 & 9 & 0 & 722 & 0 & 329 & 0 \\
\hline Microbicides & 21 & 0.00 & 0 & 0 & 21 & 0 & - & 0 \\
\hline
\end{tabular}

further research into a more strategic use of prevention investments.

\section{Acknowledgements}

The authors would like to thank Carol Nicolls for her editorial assistance.

\section{Author details}

${ }^{1}$ The Heller School for Social Policy and Management, Brandeis University, Boston, MA, USA. ${ }^{2}$ Joint United Nations Programme on HIV/AIDS (UNAIDS), 20 Avenue Apia, Geneva, Switzerland. ${ }^{3}$ Abt Associates, 4550 Montgomery Ave, Suite 800 North, Bethesda, MD 20814, USA.

\section{Authors' contributions}

PA participated in the design, conception and analysis of the study and drafted the manuscript, BG participated in the design of the study and analysis, CAF participated in the design, conception and analysis of the study, CA participated in the analysis of the study and drafting of the manuscript, PD participated in the analysis of the study and provided detailed comments on the first draft. All authors read and approved the final manuscript.

\section{Competing interests}

The authors declare that they have no competing interests.

Received: 29 November 2011 Accepted: 21 March 2012 Published: 21 March 2012

\section{References}

1. UNAIDS: AIDS at 30: Nations at the crossroads Geneva: UNAIDS; 2011.

2. Padian NS, et al: Weighing the gold in the gold standard: challenges in HIV prevention research. AIDS 2010, 24(5):621

3. Bollinger LA: How can we calculate the"E" in"CEA"? AIDS 2008, 22:S51.

4. Padian NS, McCoy SI, Abdool KS: HIV prevention transformed: the new prevention research agenda. Lancet 2011

5. Delay P: Tailoring AIDS Prevention. Science 2008, 321(5896):1631.

6. Forsythe S, Stover J, Bollinger L: The past, present and future of HIV, AIDS and resource allocation. BMC Publ Health 2009, 9(Suppl 1):S4. 
7. Izazola-Licea J, et al: Financing the response to HIV in low-income and middle-income countries. JAIDS Journal of Acquired Immune Deficiency Syndromes 2009, 52(Suppl 2):S119-S126.

8. UN General Assembly: Political Declaration on HIV/AIDS New York: UN; 2011.

9. UNAIDS: Universal access to HIV treatment, prevention, care and support Geneva: UNAIDS; 2010.

10. Health Systems 20/20 Project, and World Health Organization: Linking NASA and NHA: Concepts and Mechanics Bethesda: Health Systems 20/20 Project \& Abt Associates Inc; 2009.

11. National Institute of Allergy and Infectious Disease: The HPTN052 Study: Preventing Sexual Transmission of HIV with Anti-HIV Drugs Washington DC: $\mathrm{NIH} ; 2011$

12. Piot $P$, et al: Coming to terms with complexity: a call to action for HIV prevention. Lancet 2008, 372(9641):845-859.

13. Wilson D, Halperin DT: "Know your epidemic, know your response": a useful approach, if we get it right. Lancet 2008, 372(9637):423.

14. UNAIDS: Monitoring the Declaration of Commitment on HIV/AIDS: guidelines on construction of core indicators: 2010 Reporting Geneva: UNAIDS; 2009.

15. UNAIDS: National AIDS Spending Assessment: A Notebook on Methods Definitions and Procedures to Measure HIV and AIDS Financial Flows and Expenditures at the Country Level Geneva: UNAIDS; 2009.

16. Organization for Economic Co-operation and Development: System of Health Accounts Paris: OECD; 2000.

17. World Bank \& World Health Organization \& USAID: A Guide to Producing National Health Accounts: with special applications for low-income and middle-income countries 2003 [http://www.who.int/nha].

18. World Bank, Gross National Income per capita: Atlas Method, 2010 World Bank: Washington; 2009.

19. UNAIDS: Practical Guidelines for Intensifying HIV Prevention: Towards Universal Access Geneva: UNAIDS; 2007.

20. Schwartländer $B$, et al: Towards an improved investment approach for an effective response to HIV/AIDS. Lancet 2011, 377(9782):2031-2041.

21. UNAIDS: Making the law work for the HIV response: A snapshot of selected laws that support or block universal access to HIV prevention, treatment, care and support Geneva: UNAIDS; 2010.

22. UNAIDS: Twenty-two of the most affected countries in sub-Saharan Africa have reduced new HIV infections by more than 25\% Geneva: UNAIDS; 2010.

23. Stoneburner RL, Low-Beer D: Population-level HIV declines and behavioral risk avoidance in Uganda. Science 2004, 304(5671):714.

24. Hirnschall G, Schwartländer B: Treatment 2.0: catalysing the next phase of scale-up. Lancet 2011, 378(9787):209-211.

25. World Health Organization, UNAIDS, and UNICEF: Towards universal access: Scaling up priority HIV/AIDS interventions in the health sector Geneva: World Health Organization; 2009.

26. Matthews LT, Mukherjee JS: Strategies for harm reduction among HIVaffected couples who want to conceiv. AIDS Behav 2009, 13:5-11.

27. Fang $C T$, et al: Decreased HIV transmission after a policy of providing free access to highly active antiretroviral therapy in Taiwa. J Infect Dis 2004, 190(5):879.

28. Das $M$, et al: Decreases in community viral load are accompanied by reductions in new HIV infections in San Francisco. PLOS One 2010, 5(6): e11068.

29. Auvert B, et al: Randomized, controlled intervention trial of male circumcision for reduction of HIV infection risk: the ANRS 1265 Trial. PLoS Med 2005, 2(11):e298.

30. Bill \& Melinda Gates Foundation: Unprecedented Scale-Up of Voluntary Male Circumcision Begins in Swaziland \& Zambia 2009.

31. Mngadi S: Swaziland HIV Prevention, Response, and Modes of Transmission Analysis NERCHA; 2009

32. Leive $A, X u K$ : Coping with out-of-pocket health payments: empirical evidence from 15 African countries. Bull World Health Organ 2008, 86(11):849-856C.

\section{Pre-publication history}

The pre-publication history for this paper can be accessed here: http://www.biomedcentral.com/1471-2458/12/221/prepub

doi:10.1186/1471-2458-12-221

Cite this article as: Amico et al:: Pattern and levels of spending allocated to HIV prevention programs in low- and middle-income countries. BMC Public Health 2012 12:221.

\section{Submit your next manuscript to BioMed Central and take full advantage of:}

- Convenient online submission

- Thorough peer review

- No space constraints or color figure charges

- Immediate publication on acceptance

- Inclusion in PubMed, CAS, Scopus and Google Scholar

- Research which is freely available for redistribution

Submit your manuscript at www.biomedcentral.com/submit
C Biomed Central 